YAN Fengqiao

\title{
Tensions within the Changing Chinese Higher Education System
}

(C) Higher Education Press and Springer-Verlag 2010

The processes of "massification" and systemic change in the Chinese higher education system are closely related. Of the two, systemic change has far deeper implications.

Comprised of four academic papers, this special issue of Frontiers of Education in China might be seen as a condensed version of a research project led by Professor Ruth Hayhoe, and presented in the book Portraits of $21 s t$ Century Chinese Universities: In the Move to Mass Higher Education. It might also be seen as an alternative portrait of China's university sector. What is my reason for saying this? Although the authors of the book and the authors of this set of four articles are basically part of the same research group, the roles they have played differ considerably. The book was researched and written by four scholars living outside of China's mainland. The special issue of this journal, on the other hand, is mainly the work of four mainland-based academics. For reasons of background and proximity to the institutions being researched, the impressions and critiques of China's progress towards higher education "massification" by scholars from China's mainland as against overseas scholars are somewhat different. Actually this interaction between the two distinct groups of scholars was part of the project's original intention: a juxtaposition of "insider" and "outsider" viewpoints, which could provide a picture of China's move to mass higher education that is both objective and relatively complete. In fact, the authors of the book and the authors of the articles for this special issue are largely in agreement with regard to the factual analysis of change, while the authors from China's mainland have added some additional insights on the basis of the empirical findings of the case studies. Nevertheless the points of view of the two groups diverged somewhat in the way they interpreted the factual analysis and its theoretical implications. If the reader has a chance to read both the book and the articles in this special issue, an interesting comparison can be

YAN Fengqiao $(\square)$

Graduate School of Education, Peking University, Beijing 100871, China

E-mail: fqyan@gse.pku.edu.cn 
made. From my personal point of view, the book adopts a long-term approach to the subject. It lays out some broad observations of the Chinese higher education "massification" process, in relation to global and historical change, and is written in a stimulating and open-ended way. The articles, by contrast focus more on the shorter term, providing a look at the constraining conditions and chosen strategies of various universities, investigating the interactions of the case universities with government authorities and other social organizations. They tend to be rather concrete and expressive of tensions that have arisen in the change process.

In all the four articles in this special issue there is a clear sense of tension, and this tension is a genuine reflection of the development of Chinese higher education, especially the process of institutional change. Gong Fang and Jun Li's case analysis of Chinese key comprehensive universities reflects tensions between enhancing quality and expanding access, between responding to the demands of national authorities and meeting local needs. Zhou Guangli and Qiang Zha's analysis of key polytechnic universities and Li Mei's analysis of normal or education-related universities, reflect respectively the difficulties and dilemmas in the process of transformation from specialized institutions with a focus mainly on teaching into comprehensive and research-oriented institutions. In their analysis of the private university cases, Yan Fengqiao and Jing Lin reflect the tension between the market system and the principle of education as a public good, the contradiction between a traditional idea of civil society and the forms of commercial civil society now emerging in China. Even though these four types of institution appear to show different kinds of tension in the institutional change they are undergoing, the core or common tension they all face can be summed up in terms of a clash between tradition and modernity, realism and idealism, autonomy and responsibility, stability and change.

If we make a comparison between Chinese higher education reform and Chinese economic reform, the reader is likely to conclude that higher education reform entails greater difficulties and uncertainties. Although economic reform followed a path and rhythm determined by Deng Xiaoping's appeal for caution, "feeling for stones as one crosses the river," the direction of reform and openness was maintained and has become progressively stronger (Zheng, 2010, p. 4). In the transformation from a planned to a market system, from a closed to an open economy, the reform was confirmed by way of a combination of practical experimentation and theoretical research (Chen, 2009; Zhang, 2010). In future, China's economic development and modernization still needs to be further oriented towards the market, internationalization, democratization and the fuller development of the legal system. But in respect to higher education reform and development, we cannot look to past success in a parallel way, and draw out a clear set of policies for the next stage of development, nor is it easy to evaluate 
such past policies as the rapid enrollment expansion, institutional and department level mergers and special investment through Project 211. In terms of future development, it is also hard to point with confidence toward any clear set of directions. Higher education is embedded in the society that sustains it, and cannot be viewed in isolation. Moreover, scholars of higher education lack the kinds of objective indicators that can be used to measure economic progress.

This is not to say that Chinese higher education and economic development do not have similarities. Indeed, ultimately, China's economic and social goals are not dissimilar to those of developed countries in the West. We could go so far as to say that the aspirations of all human societies are shared. In terms of factors that influence economic growth, there can be no more important factors than capital, human resources and land (Chow, 2010; Qian, 2008, pp.188-229). The more unique features of Chinese society are evident in the way the system is organized, and the system in turn reflects the concrete institutional ways in which all kinds of social relations are constituted, including those among the economy, the government, society, religion, law and education. It should be noted that China does have some differences from other countries in terms of its institutions. For example, China's Confucian culture stresses the responsibilities of the individual, whereas in Western culture, the rights of individuals are a predominant concern. This leads to differences between Chinese and Western political and legal systems (Fairbank, 2001, p. 276). Also, China is known for a deeply conservative way of thinking that gives greater importance to morality than to scientific knowledge (Russell, 1996, p. 61). This way of thinking has to some extent limited scientific development in China. China is also a society that pays close attention to human relationships and feelings, and so is famous for the prominence it gives to "guanxi" or social connections. This has possibly slowed down the process of building a mature legal system (Chow, 2005, p. 6). The institutions responsible for economic production are under political control in China, unlike Western economies where a range of industrial or commercial organizations having the status of legal persons enjoy considerable autonomy. Clearly, the character of the system is likely to influence how a society's goals are realized. In its process of modernization, China needs to break away from its traditional systemic constraints and establish a new system that is beneficial to the development of both material and spiritual civilization. Which are the factors in the Chinese system that promote or inhibit this process of modernization? This is the question which researchers need to answer. Whether or not China's reform model can provide some kind of inspiration to others in the global community depends to a large degree on how we handle and adjust the relationships between these different institutional factors. To put this in concrete terms, the question is how China can find an effective way to reform its rigid ideology and institutional system (Zheng, 2009, p. 6). 
Similarly, China's higher education development and its potential for making a contribution to the global community is tightly connected to the effectiveness of its reforms or, we might say, to its experience of effective institutional change. It is not simply a matter of goals relating to opportunity, equity, efficiency, quality and adequacy, nor is it a matter of its scale and size. The four articles in this special issue reflect the institutional change that has taken place during the process of "massification." By this I am not referring to the superficial changes evident in enrollment expansion, mergers, participation in Projects 211 and 985 and the establishment of second-tier colleges. Rather I am referring to the deep-level changes in social interactions, including that between university autonomy and governmental control, standardization and diversification, internationalization and indigenization, change imposed from above and change resulting from bottom up decision-making processes, competition and collaboration. The authors have aimed at a rational examination of institutional changes that have produced various tensions. Whether this is a matter of value rationality or instrumental rationality, it does not easily enable us to make firm judgements. I hope that these four articles can be a kind of prologue for the continuing of a deeper level research into Chinese higher education, which can constitute an important part of future research on problems of Chinese society. The transformation of Chinese society constitutes a huge laboratory for social science research which should be viewed as an essential testing ground for evolving social scientific theories (Zheng, 2009, p. 1).

\section{References}

Chen, Z. W. (2009). 金融的逻辑 [The logic of finance]. Beijing: China International Culture Press.

Chow, G. C. (2005). 中国经济转型 [China's economic transformation]. Beijing: China Renmin University Press.

Chow, G. C. (2010). 中国经济随笔 [Notes on Chinese economy]. Beijing: China Citic Press. Fairbank, J. K. (2001). 观察中国 [China watch]. Beijing: World Affairs Press.

Qian, Y. Y. (2008). 从国际比较看中国经济 [The Chinese economy from an international comparative view]. In Zhang, W. Y. (Ed.), 中国改革 30 年: 10 位经济学家的思考 [30 years of China reform: Reflecions of ten economists]. Shanghai: Shanghai People's Publishing House.

Russell, B. (1996). 中国问题 [The problem of China]. Beijing: Academia Press.

Zhang, W. Y. (2010). 市场的逻辑 [The logic of the market]. Shanghai: Shanghai People's Publishing House.

Zheng, Y. N. (2009). 全球化与中国国家转型 [Globalization and state transformation in China]. Hangzhou: Zhejiang People's Publishing House.

Zheng, Y. N. (2010). 中国模式: 经验与困局 [China model: Experiences and difficulties]. Hangzhou: Zhejiang Publishing United Group, Zhejiang People's Publishing House. 